\title{
Antibody Dependent Cytotoxicity of Human Colostrum Phagocytes
}

\author{
H. MANDYLA, M. XANTHOU, ${ }^{(39)}$ C. MARAVELIAS, D. BAUM, AND N. MATSANIOTIS \\ First Department of Pediatrics of Athens University Athens, Greece and John Radcliffe Hospital University of Oxford, \\ Oxford, England
}

\begin{abstract}
Summary
Monocytes and polymorphonuclear neutrophils of human colostrum were identified using cytochemical staining procedures. The ability of colostral phagocytes to function in antibody dependent cellular cytotoxicity was found to be satisfactory at high effector/ target cells ratio (20:1) Colostral monocytes showed a diminished cytotoxicity when compared to monocytes of adult or neonatal peripheral blood at low effector/target cells ratio (1:1). This could be due to the extensive fat ingestion by these cells or other inhibitory factors found in colostrum.
\end{abstract}

\section{Speculation}

The demonstration of antibody dependent cellular cytotoxicity of colostral phagocytes gives further support to the biological importance of the cellular components of human milk.

There is now growing information documenting that human breast milk is superior to cow's milk in minimizing both the morbidity and mortality of infants $(3,4,29,35)$. The immunologic factors in human milk that offer resistance against infection to the neonates are summarized in several review articles $(26,28,34)$. In contrast the functions of the cellular components of human milk have received relatively little attention till recently. The white cells of human colostrum were first observed in 1839 by Alexander Donné (6). These cells were rediscovered in 1966 by Smith working in Goldman's laboratory (31). They were found to be present at concentrations of $0.5-10$ million cells $/ \mathrm{ml}$ in colostrum and comprise $30-85 \%$ macrophages, $1-80 \%$ polymorphonuclears and $1-15 \% \mathrm{~T}$ and $\mathrm{B}$ lymphocytes (17). Maternal milk contains a much lower concentration of milk cells; however, in terms of the absolute number of cells reaching the baby, the increasing volume of milk compensates for this change (17). The lymphocytes in human milk are the cells that have been most closely studied till now $(5,22$, 32). The lymphocyte population, though relatively small, appears to be quite significant in function. Milk lymphocytes were shown to respond weakly to nonspecific mitogens $(5,22)$ and to histocompatibility antigens on allogenic cells (22). They have also been shown to respond to a number of microbial antigens not necessarily the same to which blood lymphocytes from the same person respond $(21,22)$. This dichotomy of reactivity appears to reflect the accumulation of particular lymphocyte clones in the breast and the nature of mammary tissue immunity at the $T$ lymphocyte level (21).

Macrophages, which represent the majority of cells found in human milk, have been studied far less. The monocytic phagocytes are lipid laden motile cells which adhere to glass (31). They have $\mathrm{Fc}$ receptors and $\mathrm{C}_{3} \mathrm{~b}$ receptors and contain intracellular $\operatorname{IgA}(25)$. They are responsible for the synthesis of several host resistance factors of milk, including lysozyme, $\mathrm{C}_{3}$ and $\mathrm{C}_{4}$ complement components and lactoferrin $(10,25)$. Two recent studies performed to test the ability of milk phagocytes (macrophages, polymorphonuclear neutrophils) to phagocytose and kill pathogenic organisms have given contradicting results. Robinson et al. (30) found macrophages and neutrophils to phagocytose and kill Staph aureus and $E$. coli in vitro very efficiently after opsonization by the aqueous phase of milk. On the other hand Ho and Lawton (12) found good phagocytic power of colostral cells but poor killing activity of $E$. coli.

The aim of the present work was to further study the function of colostral phagocytes (monocytes and polymorphonuclear neutrophils). We tested their ability to elicit antibody-dependent cellular cytotoxicity i.e., their ability to kill anitbody-coated target cells in vitro.

We also tested the ability of peripheral blood monocytes who had phagocytosed lipid to elicit antibody-dependent cytotoxicity.

\section{MATERIALS AND METHODS}

Collection of colostrum. Colostrum was obtained from 16 women within the first 5 days following delivery. Mothers manually expressed their milk into sterile plastic containers. The samples were brought to the laboratory within one hour of collection.

Preparation of colostal cells. Because of the high fat content of colostrum, the usual procedures for identification of the white cells in the peripheral blood could not be applied. Consequently alternate methods were devised. Samples were centrifused at 200 $\times g$ for $25 \mathrm{~min}$. During centrifugation the milk separated into three layers: a cell pellet, middle layer and fat layer. The cell pellet was washed twice in Eagle's basal medium (BME) and resuspended in the same medium plus $10 \%$ foetal calf serum (FCS) Subsequently the cells were counted in a haemocytometer. The viability of cells in suspension was tested after staining the dead cells with trypan blue.

Preparation of monocyte-enriched colostral cells. In order to further separate colostral monocytes, equal parts of colostrum and culture medium S-MEM (Gibco-Bio-cult) + $10 \%$ FCS were incubated for $4 \mathrm{~h}$ in nonsiliconized glass flasks. The cultures were incubated at $37^{\circ} \mathrm{C}$ in $5 \% \mathrm{CO}_{2}$. After incubation the supernatant fluid was removed and the glass adherent cellular layer on the base of the flask was first rinsed with culture medium and then the cells were removed with Trypsin $0.25 \%$. The cells were then washed with BME $+10 \% \mathrm{FCS}$ and resuspended in the same medium.

Identification of monocytes and granulocytes. Smears were prepared using a cytocentrifuge and were subsequently stained with May-Grünwald and Giemsa stains. Because of the fat-ingestion, it was very difficult to differentiate polymorphonuclear neutrophils from monocytes.

We therefore used the combined method for nonspecific esterase and chloroacetate esterase in order to demonstrate monocytes and granulocytes simultaneously on the same cytologic preparation (38). This was done by using $\alpha$-naphthyl acetate esterase as substrate for staining nonspecific esterase of monocytes and naphthol-AS-D cloracetate esterase for staining chloroacetate esterase of granulocytes.

Preparation of blood leucocytes. Eight $\mathrm{ml}$ of heparinized venous 
blood was obtained from 11 healthy young adult volunteers and $3 \mathrm{ml}$ from 12 healthy premature neonates 3-15 days old. The gestational age of these babies ranged between 34-36 wk. All of them had normal weight for their gestational ages. Parent's written consent was obtained in all cases. Lymphocyte and monocyte mixtures were isolated on Ficoll-Hypaque gradient by the method of Böyum (1). They were then washed twice in BME.

Lipid phagocytosis by blood monocytes. Separated monocytes from the peripheral blood of six healthy adults were incubated in colostrum cell-free supernatant at $37^{\circ} \mathrm{C}$ for $2 \mathrm{~h}$. The phagocytosed lipid was identified using Sudan-black stain.

Human immune anti- $A_{1}$-serum. This was a gift from North West Thames Blood Transfusion Center. It had a haemaglutinic titre of 1:2048 against human $A_{1}$ erythrocytes. It was heat inactivated at $56^{\circ} \mathrm{C}$ for $1 \mathrm{~h}$ and the same batch was used in all experiments.

Target cells. $\mathrm{A}_{1}$ erythrocytes were obtained from a constant donor and were washed twice with BME before they were labelled with radioactive chromium.

Labelling of target cells with $\mathrm{Cr}^{51}$. A pellet of approximately $10^{8}$ $\mathrm{A}_{1}$ erythrocytes was incubated with $100 \mu \mathrm{Ci}$ of $\left[\mathrm{Cr}^{51}\right]$ chromate (Radio-chemical center Amersham, Bucks, specific activity 2-10 $\mu \mathrm{Ci} / \mathrm{mM}$ ) for $1 \mathrm{~h}$. They were then washed three times with BME and suspended in BME + FCS at a concentration of $2 \times 10^{5} / \mathrm{ml}$.

Haemolytic assay. The method used was similar to that described by Holm et al. (14). A varying number of colostral or peripheral blood effector cells (ranging from $0.125 \times 10^{6}-4 \times 10^{6}$ ) in $0.5 \mathrm{ml}$ of $\mathrm{BME}+\mathrm{FCS}$ were added to sterile plastic tubes containing $10^{5} \mathrm{~A}_{1}$ erythrocytes and antiserum to a total volume of $1.5 \mathrm{ml}$. The tubes were capped and incubated for $18 \mathrm{~h}$ at $37^{\circ} \mathrm{C}$. After $18 \mathrm{~h}$ the radioactivity of the cell-free supernatant and sediment was determined separately and the $\%$ of isotope release and the specific cytotoxicity were calculated as described by Brunner et al. (2). Assays were done in triplicate and the following controls were included in each experiment: target cells only, target and effector cells, target cells and antiserum only.

\section{RESULTS}

Cells of human colostrum. The colostral cells were mainly mononuclear macrophages, polymorphonuclear neutrophils and lymphocytes. Morphologically, the polymorphonuclear neutrophils were similar to those seen in peripheral blood except that they contained numerous fat globules (Fig. 1). Monocytes or macrophages were mononuclear cells with abundant cytoplasm containing many fat globules and other granular material (Fig. 2). Lymphocytes were found to be of various sizes, similar to those found in the blood (Fig. 2). With the double staining we used for nonspecific esterase and chloroacetate esterase, granulocytes showed red granulation whereas monocytes showed black granulation (Fig. 3). Apart from the cells already described occasional epithelial cells and epithelial cell-fragments were found in colostrum.

After the colostral white cells were separated they gave a differential count of $50-60 \%$ monocytes, $30-40 \%$ polymorphonuclear neutrophils and up to 5\% lymphocytes. Our monocyteenriched colostral white cell preparation gave a monocyte purity of around $90 \%$.

Leucocytes of adult and neonatal peripheral blood. After passing the cells through Ficoll-Hypaque gradient the differential count of the white cells obtained consisted in both adults and neonates of $80-90 \%$ lymphocytes, $10-20 \%$ monocytes and $0-2 \%$ polymorphonuclear neutrophils.

Antibody-dependent cytotoxicity of colostrum phagocytes. As shown in Figure 4 colostral phagocytes (monocytes and polymorphonuclear neutrophils) have the ability to function quite well in antibody-dependent cell-mediated cytotoxicity. The effector/target cells ratio's we used were 1:1, 2.5:1, 5:1, 10:1, 20:1, 40:1. The specific cytotoxicity of colostral phagocytes increased as the effector/target cells ratio rose from 1:1 to 20:1 $(P<0.001)$. Further increase in effector cells (40:1) caused a significant fall in cytotoxicity $(P<0.05)$.

Antibody-dependent cytotoxicity of colostrum and peripheral blood monocytes. There was no difference in the ability of neonatal and adult peripheral blood monocytes to function in antibodydependent cytotoxicity (Fig. 5). Colostrum monocytes, however, showed a reduced cytotoxic capacity when compared to those of adult $(P<0.001)$ or neonatal blood $(P<0.001)$ at low effector/ target cells ratio (1:1).

Antibody-dependent cytotoxicity of blood monocytes that had phagocytosed lipid. The antibody-dependent cytotoxicity of monocytes that had phagocytosed lipid was significantly lower $(P<$ $0.001)$ when compared with the cytotoxicity elicited from blood monocytes of the same donor that had not phagocytosed lipid (Fig. 6).

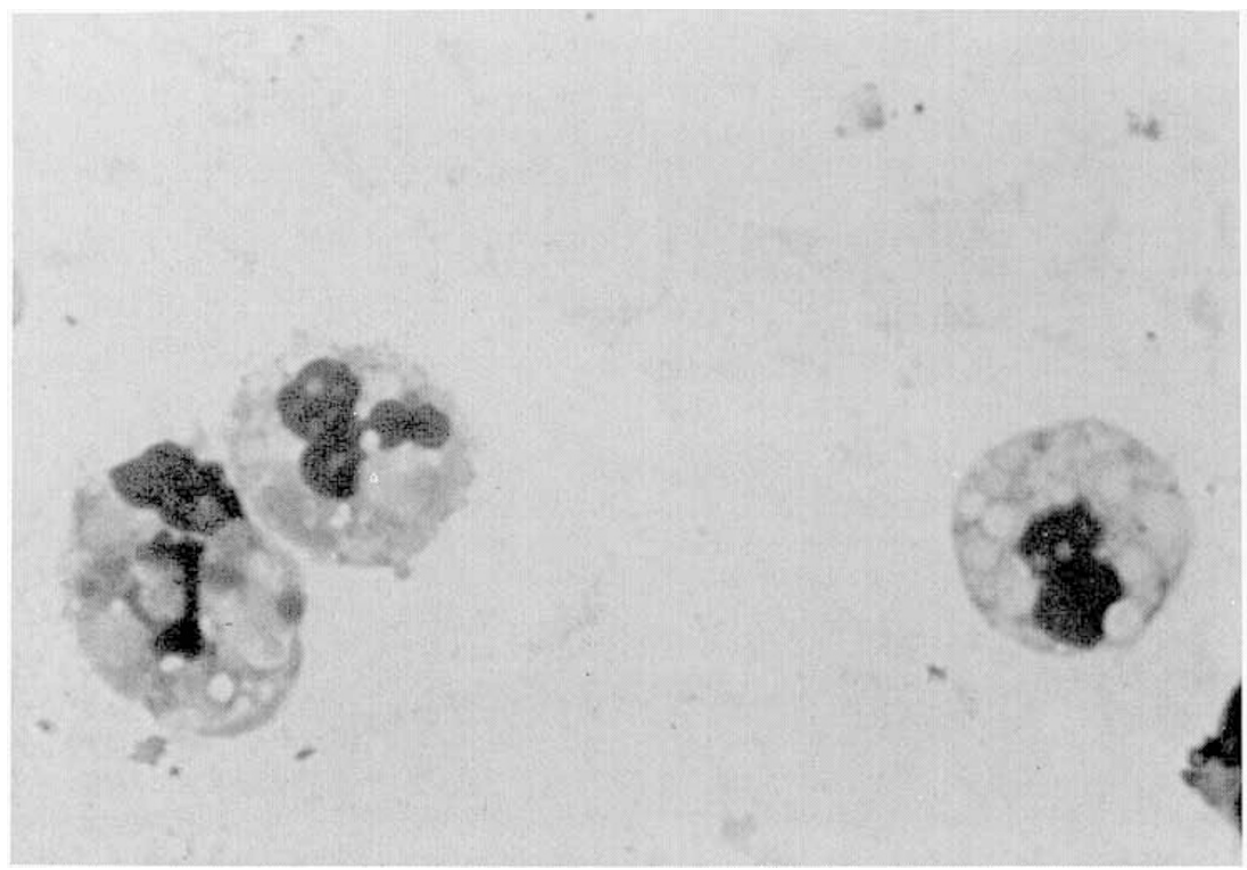

Fig. 1. Colostral neutrophils containing fat vacuoles (May-Grünwald Giemsa stain). 


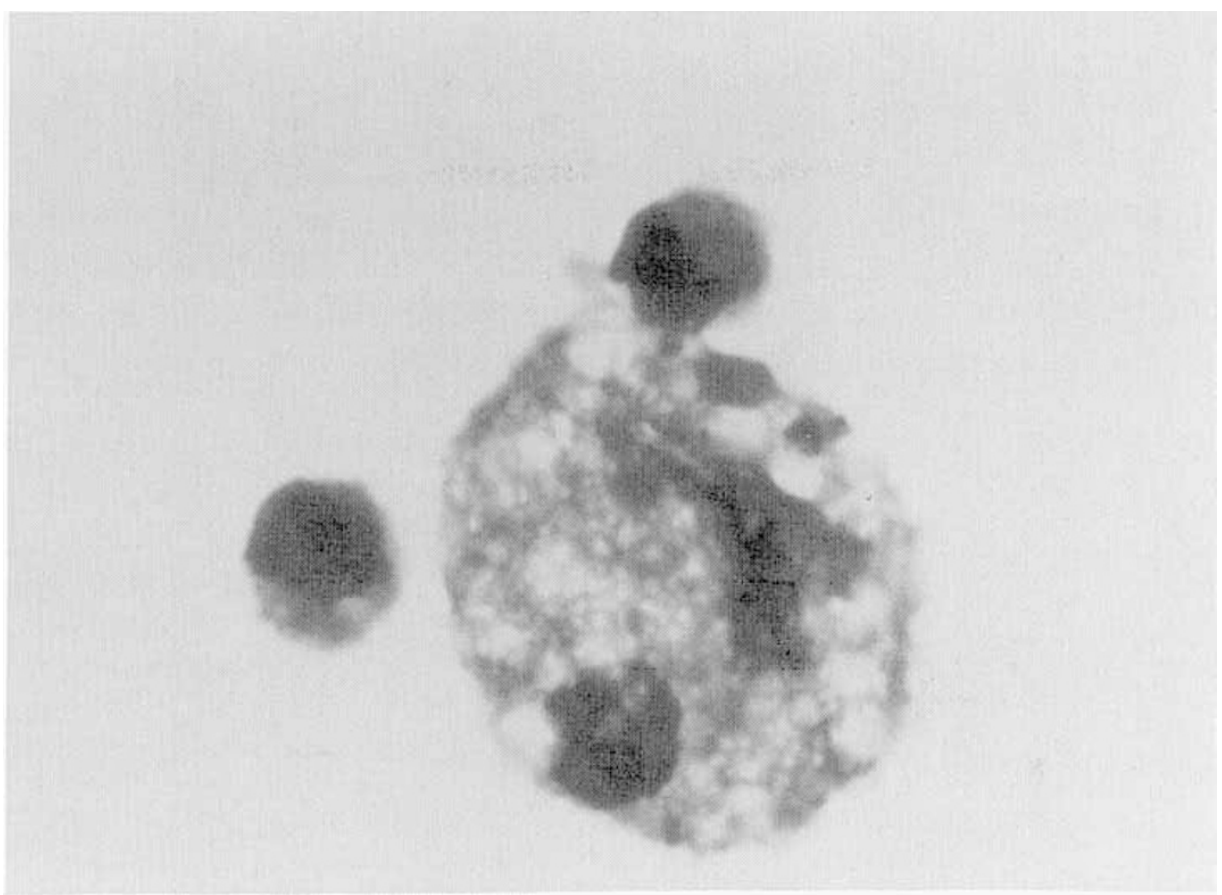

Fig. 2. A macrophage containing fat vacuoles and granular material in the cytoplasm. One of the two lymphocytes around it is shown to have a typical lymphocyte-macrophage interaction (May-Grünwald-Giemsa stain).

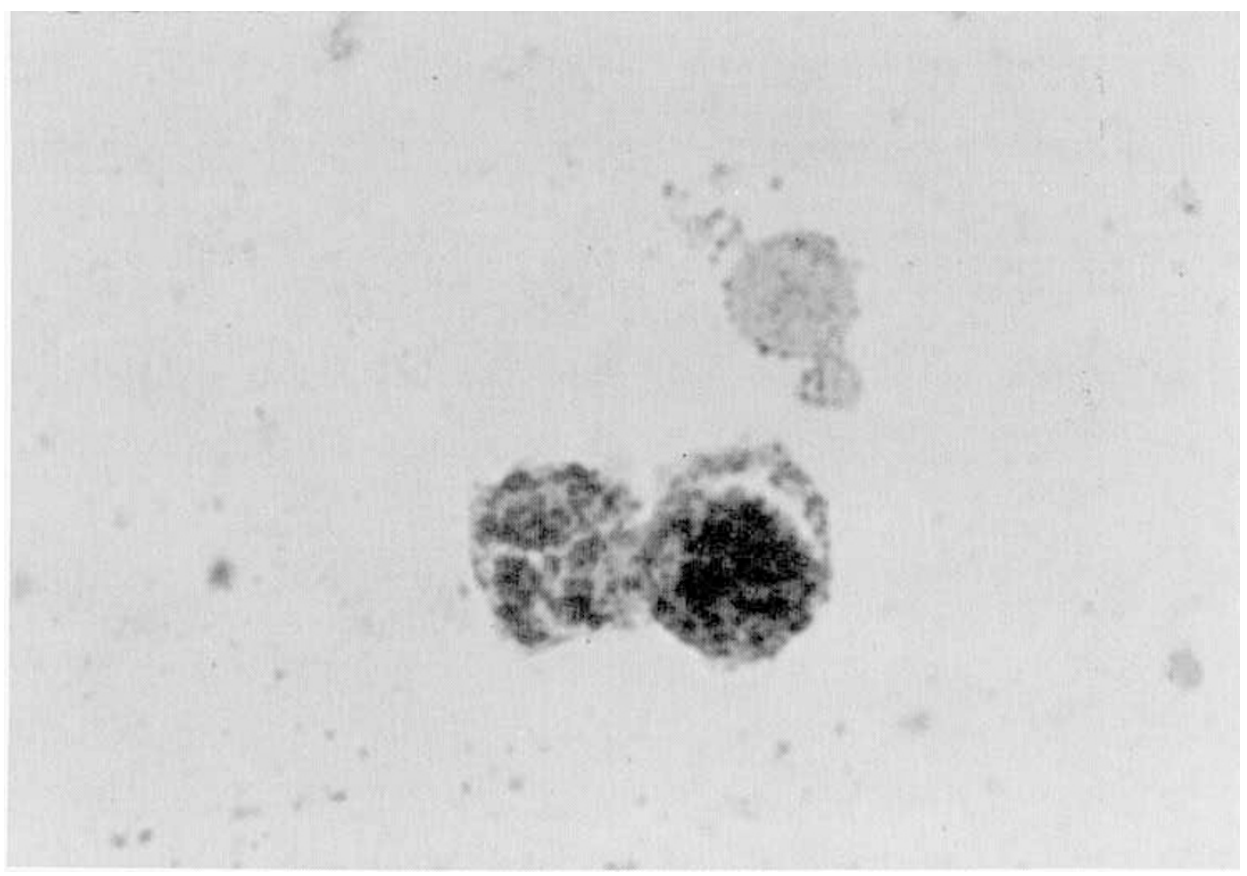

Fig. 3. $a$, A monocyte stained with a $\alpha$-naphthyl acetate and showing diffuse black granulation. $b$, A polymorphonuclear neutrophil stained with Naphthyl AS-D chloracetate esterase and showing red granulation.

\section{DISCUSSION}

We studied the colostral-phagocytes function by testing their ability to elicit antibody dependent cellular cytotoxicity (ADCC). This test in peripheral blood monocytes of adults has proved to be a reliable quantitative and qualitative assay of their function (27). This cytotoxicity involves the specific killing of antibody-coated target cells by nonimmune effector cells, which have in common the presence of a receptor for the Fc portion of IgG antibody (23). In man, lymphocytes (24) null cells or $\mathrm{K}$ cells $(36,37)$, polymor- phonuclear leukocytes (8), and monocytes and macrophages (13) have all been shown to be capable of mediating ADCC against appropriate target cells. The type of target cell and the source of antibody appear to dictate the nature of the effector cells mediating cytolysis (18). Lysis of human erythrocytes in the presence of immune iso-antibody has been reported to be effected by monocytes and polymorphonuclear leucocytes but not by lymphocytes $(9,15,18)$.

We have found that colostral monocytes and polymorphonuclear neutrophils have the ability to function in ADCC. Although 


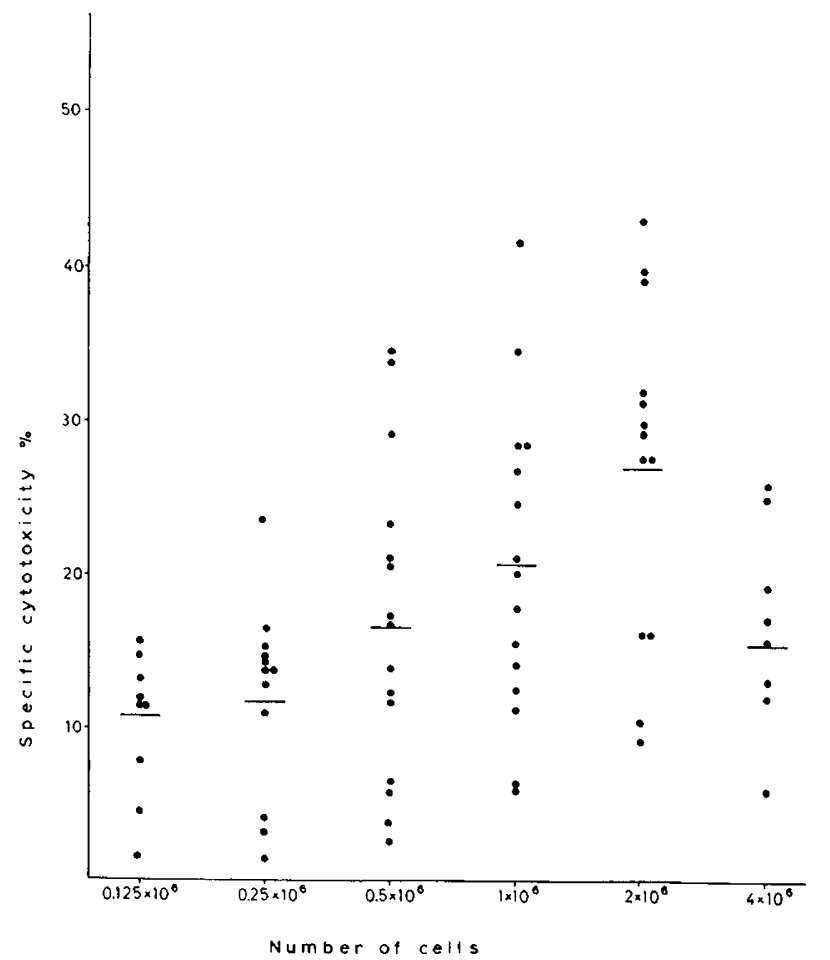

Fig. 4. Antibody-dependent-cytotoxicity of colostral phagocytes (monocytes and polymorphonuclear neutrophils). Effector/target cells ratio ranging from 1:1 to $40: 1$.

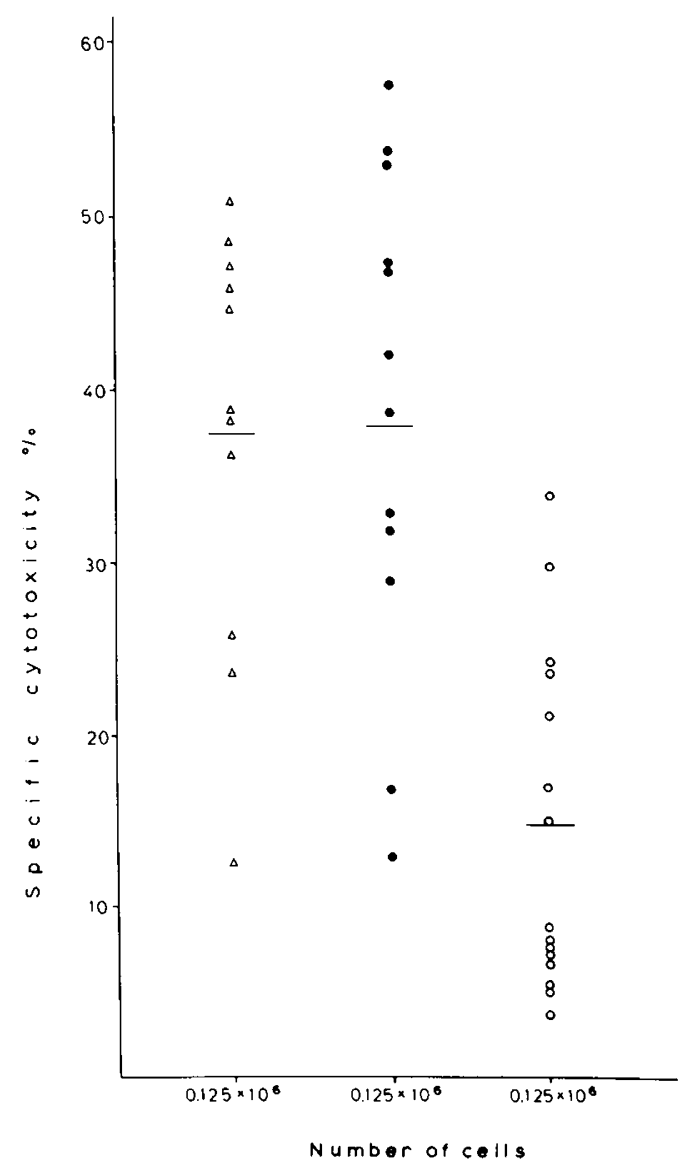

Fig. 5. Antibody-dependent cytotoxicity of colostral and peripheral blood monocytes of adults and neonates. Effector/target cells ratio 1:1 $\triangle$, adult monocytes; $\boldsymbol{\theta}$, neonatal monocytes; and $\bigcirc$, colostral monocytes.

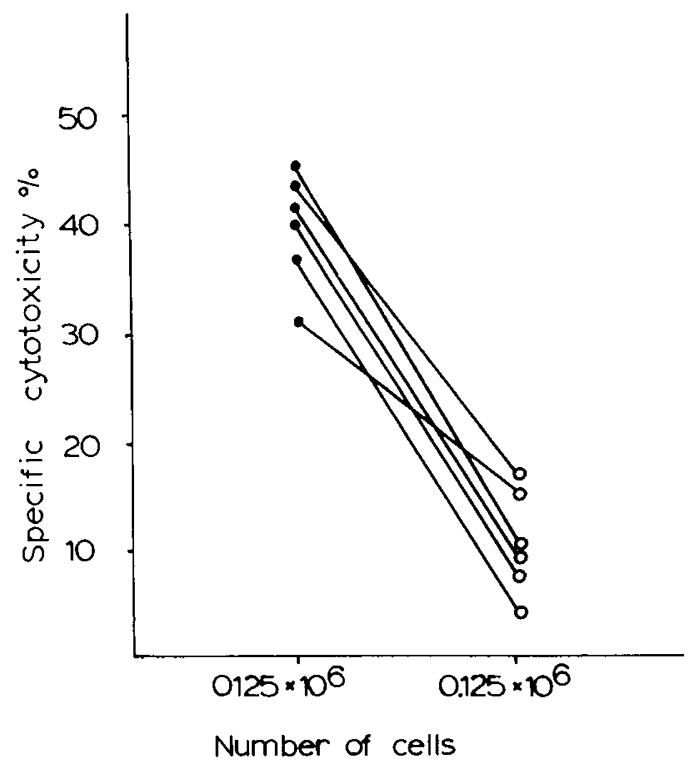

Fig. 6. Antibody dependent cytotoxicity of blood monocytes that had phagocytosed lipid. $\bullet$, Peripheral blood monocytes and O, Peripheral blood monocytes that had phagocytosed lipid.

there are a few studies on milk colostral phagocytes' ability to ingest and kill pathogenic microorganisms $(12,30)$ their ability to elicit ADCC has not presently been tested.

We subsequently tried to compare ADCC of monocytes taken from the peripheral blood of adults or neonates and colostrum.

We found no difference between adult and neonatal peripheral blood monocytes in their ability to elicit ADCC. Two previous studies, using cord blood monocytes as effector cells and human erythrocytes (19) or Herpes Simplex virus infected Chang Liver cells (16) as target, showed good ADCC.

We found colostral monocytes to have a reduced cytotoxic capacity when compared with those of adult or neonatal peripheral blood. Holm (13) and Gill et al. (9) suggested that phagocytosis is an important component of monocyte-mediated lysis. It has also been suggested that the ingestion of lipid results in disruption of lysosome and depletion of lysosomal enzymes. And indeed our experiments showed peripheral blood monocytes who had phagocytosed lipid to have a significantly lower cytotoxic ability. Moreover, Holm and Hammarström (15) have shown that loading of peripheral blood monocytes with heat-killed candida albicans or carbonyl iron particles suppressed their haemolytic action. However, there are other studies claiming that monocytes are capable of mediating cytolysis through an extracellular lytic process ( 7, 8, 11). At the present time, the mechanism by which normal monocytes destroy antibody-coated erythrocytes is not completely understood.

The reduced monocyte cytotoxicity could also be attributed to other colostral factors analogous to those which cause the lymphocytes of the colostrum to show a reduced response to phytohaemaglutinin (5). Finally the fat globules, which are attached to the monocyte surface, may block the contact of their Fc receptors to the antibody coated erythrocytes.

From our results it is obvious that colostral phagocytes show good cytotoxic activity particularly at effector/target cells ratio of 20:1. What is the significance of this colostral leucocyte function in vivo? Pitt et al. (25) in an elegant study demonstrated in a rat model that Klebsiella-induced necrotizing enterocolitis could be prevented by feeding rat colostral macrophages but not by feeding the soluble colostral factors. Similar experiments have not been performed in human neonates but epidemiologic studies have suggested that necrotizing enterocolitis is less common among infants fed with untreated breast milk $(20,33)$. There seem little doubt that there is a definite biologic significance in the living functional phagocytes of the human colostrum, however further 
studies are needed to clarify the magnitude and importance of their contribution to the infants host defence mechanisms.

\section{REFERENCES AND NOTES}

1. Böyum, A.: Isolation of mononuclear cells and granulocytes from human blood. Isolation of mononuclear cells by one centrifugation and of granulocytes by combined centrifugation and sedimentation at Ig. Scand. J. Clin. Lab. Invest. 21, Suppl. 97: 77 (1968).

2. Brunner, K. T., Manel, J., Cerottoni, J. C., and Chapuis, B.: Quantitative assay of the lytic action of immune lymphoid cells on $\mathrm{Cr}^{5 i}$ labelled allogeneic target cells in vitro. Inhibition by isoantibody and by drugs. Immunology, 14: 181 (1968).

3. Cunningham, A. S.: Morbidity in breast-fed and artificially fed infants. J. Pediatr., 90: 726 (1977).

4. Cunningham, A. S.: Morbidity in breast-fed and artificially fed infants. H. J. Pediatr., 95: 685 (1979).

5. Diaz-Jouanen, E. and Williams, R. C.: T and B lymphocytes in human colostrum, Clin. Immunol. Immunopathol., 3: 248 (1974).

6. Donnë, A.: Cours de microscopie. Vol. 1 et Atlas No 1 (Bailliëre, Paris, 1844-45).

7. Gale, P. R. and Zighelboim, J.: Polymorphonuclear leucocytes in antibodydependent cellular cytotoxicity. J. Immun., 114: 1047 (1975).

8. Gale, P. R. and Zighelboim, J.: Modulation of polymorphonuclear leucocytemediated antibody-dependent cellular cytotoxicity. J. Immunol. 113: 1973 (1974).

9. Gill, P. G., Waller, C. A., MacLennan, and I. C. M.: Relationships between different functional properties of human monocytes. Immunology, 33: 873 (1977).

10. Goldman, A. S. and Smith, C. W.: Host resistance factors in human milk. J. Pediatr. 82: 1082 (1973).

11. Hibbs, J. B.: Heterocytolysis by macrophages activated by Bacillus CalmetteGuerrin. Lysosome exocytosis into tumor cells. Science 184: 468, (1974).

12. Ho, P. C. and Lawton, J. W. M.: Human colostral cells: phagocytosis and killing of E. coli and C. Albicans. J. Pediatr., 93: 910 (1978).

13. Holm, G.: Lysis of antibody-treated human erythrocytes by human leukocytes and macrophages in tissue culture. Int. Arch. Allergy, 43: 671 (1972).

14. Holm, G., Engwall, E., Hammarstrom, S., and Natvig, J. B.: Antibody-induced haemolytic activity of human blood monocytes. The role of antibody class and subclass. Scand. J. Immunol., 3: 173 (1974).

15. Holm, G. and Hammarstrom, S.: Haemolytic activity of human blood monocytes Lysis of human erythrocytes treated with anti-A-serum. Clin. Exp. Immunol., 13: 29 (1973).

16. Kohl, S., Shaban, S. S., Starr, S. E., Wood, P. A., and Nahmias, A. J.: Human neonatal and maternal monocyte-macrophage and lymphocyte-mediated antibody-dependent cytotoxicity to cells infected with herpes simplex. J. Pediatr., 93: 206 (1978)

17. Lawton, J. W. M. and Shortridge, K. F.: Protective factors in human breast milk and colostrum. Lancet, $1: 253$ (1977)

18. MacDonald, H. R., Bonnard, G. D., Sordat, B., and Zawodnik, S. A.: Antibodydependent cell-mediated cytotoxicity. Heterogeneity of effector cells in human peripheral blood. Scand. J. Immunol. 4: 487 (1975).
19. Milgrom, H. and Shore, S. L.: Assessment of monocyte function in the normal newborn infant by antibody-dependent cellular cytotoxicity. J. Pediatr., 91: $612(1977)$.

20. Mizzawi, A., Barlow, O., Berdon, W., Blanc, W. A., and Silverman, W. A. Necrotizing enterocolitis in premature infants. J. Pediatr. 66: 697 (1965).

21. Parmely, M. J. and Beer, A. E.: Colostral cell-mediated immunity and the concept of a common secretory immune system. J. Dairy Sci.. 60: 655 (1976).

22. Parmely, M. J., Beer, A. E., and Billingham, R: E.: In vitro studies on the Tlymphocyte population of human milk. J. Exp. Med., 144: 358 (1976).

23. Perlman, P. and Holm, G.: Cytotoxic effects of lymphoid cells in vitro. Adv. Immunol., 11: 117 (1969).

24. Perlman, P., Perlman, H., and Wigzell, H.: Lymphocyte mediated cytotoxicity in vitro: Induction and inhibition by humoral antibody and nature of effector cells. Transplant. Rev., 13: 91 (1972).

25. Pitt, J., Barlow, B., and Heird, W. C.: Protection against experimental necrotizing enterocolitis by maternal milk. I. Role of milk leukocytes. Pediatr. Res., II 906 (1977).

26. Pittard, W. B.: Breast milk immunology. Am. J. Dis. Child., 133: 83 (1979).

27. Poplack, D. G., Bonnard, G. D., Holiman, B. J., and Blaese, R. M.: Monocytemediated antibody-dependent cellular cytotoxicity: a clinical test of monocyte function. Blood, 48: 809 (1976).

28. Relter, B.: Review of the progress of Dairy Science: antimicrobial systems in milk. J. Dairy Res., 45: 131 (1978).

29. Robinson, M.: Infant morbidity and mortality. Lancet, 210: 788 (1951)

30. Robinson, J. E., Harvey, B. A. M., Soothill, J. F.: Phagocytosis and killing of bacteria and yeast by human milk cells after opsonization in aqueous phase of milk. Br. Med. J., I: 1443 (1978)

31. Smith, C. W. and Goldman, A. S.: The cells of human colostrum. I. In vitro studies of morphology and functions. Pediatr. Res., 2: 103 (1968).

32. Smith, C. W., Goldman, A. S., and Yates, R. D.: Interactions of lymphocytes and macrophages from human colostrum. Electron microscopic studies of the interacting lymphocyte. Exp. Cell. Res., 69: 409 (1971).

33. Touloukian, R., Berton, W., Amoury, R., and Santulli, T. V.: Surgical experience with necrotizing enterocolitis. J. Pediatr. Surg., 2: 389 (1967).

34. Welsh, J. K. and May, J. T.: Anti-infective properties of breast milk. J. Pediatr., 94: 1 (1979).

35. Winberg, J. and Wessmer, G.: Does breast milk protect against septicaemia in the newborn? Lancet $1:$ I091 (1971).

36. Wisløff, F., Frøland, S. S., and Michaelson, T. E.: Antibody-dependent cytotoxicity mediated by human $\mathrm{Fc}$-receptor-bearing cells lacking markers for $\mathrm{B}$ and T -lymphocytes. Int. Arch. Allergy Appl. Immunol., 47: 139 (1974).

37. Xanthou, M., Mandyla-Sfagou, E., Campbell, A. C., Waller, C. A., EconomouMavrou, C., and Matsaniotis, N.: Lymphocyte subpopulations and their function in the blood of neonates, In: Intensive Care in the Newborn. Eds. L. Stern, B. Friis-Hansen and P. Kildeberg, p. 139. (Masson, New York, 1976).

38. Yam, L. T., Li, C. Y., and Crosby, W. H.: Cytochemical identification of monocytes and granulocytes. Am. J. Clin. Pathol., 55: 283 (1971).

39. Requests for reprints should be addressed to: Dr. M. Xanthou, Neonatal Intensive Care Unit, First Department of Pediatrics of Athens University, Aghia Sophia Children's Hospital, Athens 608, Greece.

40. Received for publication March 16, 1981.

41. Accepted for publication December 9,1981 